Article

\title{
Family Business Succession in Different National Contexts: A Fuzzy-Set QCA Approach
}

\author{
José António Porfírio ${ }^{1, *}$, Tiago Carrilho ${ }^{1}$, Joseph Hassid ${ }^{2}$ and Ricardo Rodrigues ${ }^{3}$ \\ 1 CIEO - Research Centre for Spatial and Organizational Dynamics, Social Sciences and Management \\ Department, Universidade Aberta, 1269-001 Lisbon, Portugal; Tiago.Mendes@uab.pt \\ 2 Department of Economics, University of Piraeus, 18534 Piraeus, Greece; jhassid@unipi.gr \\ 3 Centre for Management Studies, ISEG-Lisbon School of Economics and Management, 1249-078 Lisbon, \\ Portugal; cege@iseg.ulisboa.pt \\ * Correspondence: Jose.Porfirio@uab.pt; Tel.: +351-962-145-117
}

Received: 1 August 2019; Accepted: 3 November 2019; Published: 10 November 2019

check for updates

\begin{abstract}
Family business succession is a key topic that has attracted considerable attention from researchers, especially in the last decade. Most research, however, is based on case studies with limited applicability and fails to present comparisons across international contexts that highlight differences in succession processes. We apply expectation states theory to analyze a sample of 128 observations in two Southern European countries, Portugal and Greece. We study configurations of successors' characteristics, family business characteristics, the existence (or absence) of a succession plan, and successors' motivation to succeed. Our aim is to reveal how these issues affect successors' perceptions of preparation for succession using fuzzy-set qualitative comparative analysis (fsQCA). Family businesses are a dominant organizational form all over the world, and succession issues are critical for the sustainability of family businesses. Our findings suggest that different configurations of conditions influence successors' perceptions of preparation for family business succession. Moreover, we verify the influence of cultural differences on these processes. This research helps fill a gap in the literature, showing the role of a set of characteristics in successors' perceptions of preparation for family business succession. Our conclusions provide insight into the types of policies that can promote successful family business succession.
\end{abstract}

Keywords: family business; succession process; motivation for succession; cross-country analysis; expectation states theory

\section{Introduction}

Family businesses are the most common form of entrepreneurial organization in the world [1]. They seem to be the invisible hand responsible for economic and social development in the European Union [2], and their importance extends to other parts of the world [3]. Family business succession is a recent [4] and prominent [5] field of research and, for sustainability reasons, is becoming increasingly relevant. This increased relevance is because succession may have important implications for regional economic, sociological, and environmental development. Studies in this field usually cover subjects such as gender [3,6-9], formal level of education and training of successors [10,11], successors' preparation and ability to lead the business [12-14], successors' willingness and commitment [4,15-17], and the use of strategic planning in the succession process [18-20]. However, scholars have devoted less attention to studying, either jointly or in isolation, the effects of age, gender, motivation, and successors' perceptions of preparation on the success of succession. These issues affect self-efficacy of successors in family businesses and may therefore hinder successful family business succession [21]. 
Likewise, country differences, especially cultural differences between countries, in succession processes have scarcely been explored (e.g., [4,5]).

Despite previous research on family business succession, it has often been noted that just one third of family businesses continue beyond the first generation, and only about $10 \%$ to $15 \%$ go beyond the second generation [22,23]. Therefore, this research is important to enrich our knowledge of succession processes, which are critical for business- and family-related objectives [5], to support the development of more effective public policies that can drive family business success and sustainability in Europe.

In this paper, we use expectation states theory [24] to analyze 128 family businesses from Greece ( 87 family businesses) and Portugal (41 family businesses). We study the effect of the individual characteristics of family business successors (gender, age, educational level, and motivation) and the characteristics of the family business itself (size and generation) on successors' perceptions of preparation for succession. Expectation states theory may explain the influence of these factors on successors' self-efficacy and may shed light on how family business successors' perceptions of preparation for succession influence the success of the succession process. We use fuzzy-set qualitative comparative analysis (fsQCA) to characterize these relationships and analyze the patterns described in our model.

The purpose of this article is to identify and study the conditions that are present or absent when successors have high or low perceptions of preparation for succession. The first objective is to analyze the effect of individual and family business characteristics on the perception of preparation for succession. The second objective is to analyze the effect of motivation and the influence of the succession plan on the perception of preparation for succession. The third objective is to analyze the importance of context in the research model.

In the following sections, we present the literature review, the research methods (propositions, research model, conditions and outcome, and analysis instruments), results and analysis, discussion, and conclusions and contributions. We end the paper by presenting limitations and proposals for future research.

\section{Literature Review}

Expectation states theory helps explain how interactional status structures form and develop in equal and different social groups [25-28]. It is specifically related to how "people's socially significant characteristics, such as race, gender, occupation, or age, shape their access to participation, influence, and positive evaluation" and how, through direct and indirect effects, these characteristics influence social stratification ([25], p. 30). From the economic observation of businesses, expectation states theory can arguably also be applied to the conditions for successful family business succession. In particular, expectation states theory can be used to explain how socially significant characteristics can influence successors' perceptions of preparation for succession. By hindering successors' self-efficacy, successors' perceptions will be a crucial issue to explain the success of family business succession processes.

Successors' preparation and ability to lead the business are related to positive succession outcomes $[12,13,29]$. There is also a significant correlation between successors' preparation and successful succession processes [30-33]. More specifically, a business's survival during a transitional process is associated with the successor's development [34]. A successor's readiness to take over is positively and significantly related to the incumbent's satisfaction with the succession process [35]. Higher financial sunk costs (investment of money) and higher behavioral sunk costs (investment of energy and time) for successors are associated with greater perceptions of firm value. These greater perceptions in turn influence successors' decisions regarding whether to sell the firm [36].

\subsection{Individual Characteristics}

Various studies have shown that there are differences between women- and men-owned businesses in terms of both success and failure [37-39]. In succession processes, access to bank capital can be easier for male-led businesses than for female-led businesses, whereas access to family funding and 
other opportunities tend to be easier for female-led businesses [6-9,40]. Women who work with their families tend to report higher incomes, better positions, and more flexibility in work schedules $[9,14]$ and usually experience feelings of greater protectionism by their fathers [41,42]. These situations usually inhibit open discussion of succession plans and may require specific provisions to support female successors [4] against expectations of greater male competence or other stereotypes [25]. In their case-study of 10 female family business owners, Vera and Dean [43] concluded that the majority of these owners did not feel discrimination and that those who did feel discrimination felt less discrimination from employees than from outsiders. In businesses that mothers had founded, daughters had to deal with their mothers' reluctance to give up business leadership [43]. Crucially, the use of a binary independent variable for gender has methodological limitations. Gender influences not only family trajectories, functions, and interactions but also business decisions, structures, and processes. Gender also provides better knowledge of the diversity of family patterns across and within societies [44]. Examining family members' interactions, cultural norms, and beliefs also reveals close linkages between masculinity, entrepreneurship, and family business that influence the selection process of the successor, given gendered roles and hierarchies [3]. Having a female CEO in a family business has a non-significant moderating effect on a family business's probability of facing financial distress [45]. This finding is relevant because a family business's probability of facing financial distress can affect the company's survival probability and potential ability to generate income or welfare for the family, which, in turn, is associated with transgenerational sustainability intent.

The effect of successors' age on the succession process has scarcely been explored in the literature. As far as a family's approach is concerned, succession planning is often strongly related to the founder's age $[46,47]$. Vera and Dean [43] also concluded that a successor's viability is related to being the oldest offspring, regardless of gender.

The factors that influence succession in family businesses include the successor's formal level of education and training. This is one of the variables that are usually studied [48-51], and it is considered one of the most influential characteristics in successful transitions [10] because formal education and attendance at business-related courses and seminars influence the successor's competence and readiness to increase revenue and profit [11]. The successor's formal training (especially in business or relevant technical domains) also provides a large array of skills to capture the increasing complexity of global business [11], promote innovation [52], and improve the successor's willingness to implement change [53]. Internal family successors are prioritized when the high importance of business-specific and tacit knowledge is combined with a high importance of general or technical industry-specific knowledge [54]. Successful successors tend to have a solid educational background that prepares them well [10].

\subsection{Motivation for Succession}

Successful succession is also linked to the willingness and commitment of the successor $[4,15,16,55,56]$, which, in turn, is usually related to the successor's motivation to succeed. The potential successor's refusal of the position or the founder's refusal to appoint the successor can be explained by the successor's lack of motivation or dissatisfaction. This lack of motivation or dissatisfaction can even prevent succession in family businesses [57]. In this context, Cabrera-Suárez and Martín-Santana [5] highlighted the distinction and influence of the normative dimension of commitment on the affective dimension of commitment (most likely to induce high job-related performance). Besides the normative and affective dimensions, Sharma and Irving [17] also studied the calculative and imperative bases, which may coexist, of successor commitment, considering that despite these bases, all commitment may contribute positively to succession, even if it leads to distinct discretionary behaviors within the business. Additionally, commitment may change over the years [17].

Financial attractiveness of family businesses is important to increase successors' willingness to run the business. A decline in business performance usually causes successors to seek opportunities outside the family business [58]. The reasons for women to join family businesses relates to working part-time, 
having a flexible schedule, and receiving family support [43]. A successor's positive succession experience is related to the successor's fulfilment in terms of life stage needs, career interests, and psychosocial needs [59].

\subsection{Family Business Characteristics}

A negative correlation between the size of the family business and the successor's intentions to leave the company has been posited [60]. The smaller the company is, the stronger the successor's perception of future unattractiveness in terms of monetary and non-monetary rewards will be [11]. As a limited number of family members are able and willing to join the business, dependence on non-family members increases as family businesses grow [61]. The acceleration in the growth of family businesses may be associated with new ideas and necessary skills provided by non-family managers [61]. For offspring in general, the succession of a non-founding family member is less challenging than the succession of the founder [43]. A weaker growth orientation and a lower debt ratio in the firm are the result of wealth preservation objectives of second-generation family businesses [62]. Third- or later-generation firms are usually associated with lower risk aversion and less conflict between incumbents and successors [62]. Family succession results in poorer performance, especially in well-performing founder-run businesses in competitive sectors [63]. This performance decrease is lower in non-family-run firms than in companies managed by successors [63].

\subsection{Succession Plan}

Strategic planning may lead to the long-term success of a family business $[18,19,64,65]$, help family businesses benefit from their innovation capabilities [66], and improve their capacity to rapidly pursue opportunities and dominate markets [67]. Strategic planning in family businesses can be an important factor in guaranteeing the increased involvement of successors in the business [20], and succession planning [35] can help towards family business continuity and family harmony [4]. However, succession may need other conditions to guarantee success [68].

The role of the next generation before the succession process may be that of an observer. Alternatively, the next generation may be involved as part of the team that executes the strategic plan, perhaps even implementing the plan by taking a lead role in the process [20]. In terms of preparation for succession, cases where successors are mere observers that have just joined the business have been found to differ considerably from cases where the next generation has already been involved in the leadership of the business or the strategic planning process [20]. This process is aligned with the argument about the importance of the long-term perspective on succession [14] and can also be analyzed using expectation states theory.

Succession patterns may be influenced by the governance and culture of an organization. Conservative patterns are more common in traditional, stable contexts, wavering patterns are more likely in fragmented and politicized organizations, and rebellious patterns are more prevalent in turbulent or problem-ridden situations [69]. Successful transitions are related to informal planning inherent to business and family dynamics that prioritize change and ongoing adaptation [10]. The satisfaction of successors with the succession process is influenced by succession planning [35]. According to Helin and Jabri [70], studying family conversation enrichment in a living moment implies thinking beyond the predefined issues of succession planning and predefined steps inherent to traditional stage models of succession planning.

\section{Methods}

\subsection{Research Model and Propositions}

Based on the literature review, the conceptual model (Figure 1) shows the proposal of how the individual characteristics of the successor, the characteristics of the family business, the motivation to succeed, and the existence of a succession plan contribute to successors' perceptions of preparation to 
run the family business in the future. Based on previous literature [5,71-74], the importance of national context is also considered. Cultural beliefs regarding individuals' socially significant characteristics may be associated with expectations regarding performance [25].

\begin{tabular}{|l||l|l|}
\hline Individual Characteristics & & Country \\
\hline \hline Motivation for Succession & & $\begin{array}{l}\text { Perceived Preparation } \\
\text { for Succession }\end{array}$ \\
\hline \hline Family Business Characteristics & & \\
\hline \hline Succession Plan & \\
\hline
\end{tabular}

Figure 1. Conceptual model.

The propositions, which are based on the literature and the principles of expectation states theory, can be formally stated as follows:

P1: The individual characteristics of the family business successor, considering the influence on social stratification, are present or absent in solutions leading to high and low perceived preparation for succession.

P2: The successor's motivation to succeed is present or absent in solutions leading to high and low perceived preparation for succession.

P3: The characteristics of the family business are present or absent in solutions leading to high and low perceived preparation for succession.

P4: The existence of a succession plan is present or absent in solutions leading to high and low perceived preparation for succession.

P5: National context influences the configurations of conditions associated with high and low perceived preparation for succession.

\subsection{Methodology, Conditions, and Outcome}

We used fuzzy-set qualitative comparative analysis (fsQCA). This method, which was initially developed for small- and medium-sized samples [75], is based on set theory and Boolean algebra [76]. In fsQCA, the existence of equifinal solutions is assumed, which is an advantage relative to conventional quantitative approaches. FsQCA allows for the existence of asymmetric relationships [77]. We used fsQCA to identify configurations of conditions (corresponding to cases) associated with a certain outcome. Despite only recently being introduced in the social sciences [76], fsQCA is an alternative to quantitative methods [75] that has become a prominent method in research in several management fields, including marketing, innovation, and entrepreneurship [78]. Cases (i.e., observations) are grouped according to their characteristics, enabling the identification of patterns of conditions (i.e., variables after being calibrated) that are present or absent when a certain outcome occurs (in this case, successors' perceptions of preparation for succession).

The first step of fsQCA [78] is to calibrate the original data into fuzzy-set membership scores ranging from 0 (full non-membership) to 1 (full-membership), where 0.5 is the point of indifference or maximum ambiguity [76]. For the outcome, we considered the 90th and 10th percentiles [79]. To avoid maximum ambiguity, whenever the fuzzy-set score was 0.5 , it was replaced by 0.499 [80]. The second step focused on the truth table algorithm [78]. From an initial set of rows representing all logically possible combinations of the conditions under analysis, the truth table algorithm identifies the combinations that are sufficient to produce the outcome or, in this research, to obtain the intermediate solutions for the presence and absence of the outcome for the Greek and Portuguese samples. The number of solutions for each outcome may vary according to the diversity in the sample. Table 1 presents the conditions, outcome, and the calibration from the original scales. 
Table 1. Conditions and outcome.

\begin{tabular}{|c|c|c|c|c|c|c|}
\hline Aggregate & Conditions & Description & Original Scale & References & Calibration & Descriptive Statistics \\
\hline \multirow{3}{*}{$\begin{array}{l}\text { Individual } \\
\text { Characteristics }\end{array}$} & Gender & $\begin{array}{l}\text { Gender of the family } \\
\text { business successor }\end{array}$ & Male or female & {$[9,37-42]$} & $\begin{array}{l}\text { Female }=1 \\
\text { Male }=0\end{array}$ & $\begin{array}{l}\text { Females account for } \\
37.5 \% \text { of the sample }\end{array}$ \\
\hline & Age & $\begin{array}{l}\text { Age of the family } \\
\text { business successor }\end{array}$ & $18-25 ; 26-30 ; 31-35 ; 35+$ & {$[46,47]$} & $\begin{array}{c}>35(\text { older })=1 \\
18-35 \text { (younger })=0\end{array}$ & $\begin{array}{l}\text { Older family business } \\
\text { successors account for } \\
62.5 \% \text { of the sample }\end{array}$ \\
\hline & Education & $\begin{array}{l}\text { Maximum level of } \\
\text { formal or informal } \\
\text { instruction reached by } \\
\text { the family business } \\
\text { successor }\end{array}$ & $\begin{array}{l}\text { High school; university level; } \\
\text { post-graduate; and vocational } \\
\text { education training }\end{array}$ & {$[10,48-53]$} & $\begin{array}{c}\text { University level or } \\
\text { post-graduate (high) }=1 \\
\text { High school or } \\
\text { vocational education } \\
(\text { low })=0\end{array}$ & $\begin{array}{l}\text { University level or } \\
\text { post-graduate } \\
\text { account for } 84.4 \% \text { of } \\
\text { the sample }\end{array}$ \\
\hline $\begin{array}{l}\text { Motivation for } \\
\text { Succession }\end{array}$ & Motivation & $\begin{array}{l}\text { Perceived motivation } \\
\text { of successors for the } \\
\text { "announced" } \\
\text { succession }\end{array}$ & $\begin{array}{l}\text { (1) I had no alternative; (2) My } \\
\text { family expected me to inherit the } \\
\text { business; (3) It seemed to be the } \\
\text { natural course of events; (4) It } \\
\text { seemed a good career } \\
\text { opportunity; or (5) I thought it } \\
\text { would be an opportunity to put } \\
\text { innovative ideas to practice. } \\
\text { Answers (1), (2), and (3) were } \\
\text { classified as not proactive, and } \\
\text { answers (4) and (5) were } \\
\text { classified as proactive toward } \\
\text { succession }\end{array}$ & {$[4,5,15,16,55,56]$} & $\begin{array}{l}\text { Non-proactive }(\text { low })=0 \\
\text { Proactive }(\text { high })=1\end{array}$ & $\begin{array}{c}\text { Proactive motivation } \\
\text { accounts for } 50.8 \% \text { of } \\
\text { the sample }\end{array}$ \\
\hline \multirow[t]{2}{*}{$\begin{array}{l}\text { Family Business } \\
\text { Characteristics }\end{array}$} & Maturity & $\begin{array}{l}\text { Maturity of the family } \\
\text { business based on the } \\
\text { number of family } \\
\text { generations so far }\end{array}$ & $\begin{array}{l}\text { 2nd generation; 3rd generation; } \\
\text { older than 3rd generation }\end{array}$ & {$[13,31]$} & $\begin{array}{c}\text { 2nd generation }=0 \\
\text { 3rd generation or more } \\
(\text { high })=1\end{array}$ & $\begin{array}{l}\text { 3rd generation or } \\
\text { more account for } \\
29.7 \% \text { of the sample }\end{array}$ \\
\hline & Size & $\begin{array}{l}\text { Number of employees } \\
\text { of the family business }\end{array}$ & $1-9 ; 10-49 ; 50-99 ; 100-249 ; 250+$ & {$[11,14,60]$} & $\begin{array}{c}1-9(\text { micro })=0 \\
10-249(\text { SMEs })=1\end{array}$ & $\begin{array}{l}\text { SMEs account for } \\
58.6 \% \text { of the sample }\end{array}$ \\
\hline
\end{tabular}


Table 1. Cont.

\begin{tabular}{|c|c|c|c|c|c|c|}
\hline Aggregate & Conditions & Description & Original Scale & References & Calibration & Descriptive Statistics \\
\hline Succession Plan & Plan & $\begin{array}{l}\text { Does a plan exist for } \\
\text { succession in the } \\
\text { family business? }\end{array}$ & Yes or no & {$[4,20,35,66,67]$} & $\begin{array}{l}\mathrm{No}=0 \\
\mathrm{Yes}=1\end{array}$ & $\begin{array}{l}17.2 \% \text { of the family } \\
\text { businesses in the } \\
\text { sample have a } \\
\text { succession plan }\end{array}$ \\
\hline Context & Country & $\begin{array}{c}\text { Country of origin and } \\
\text { where the family } \\
\text { business operates }\end{array}$ & Portugal or Greece & {$[5,81-83]$} & N/A & $\begin{array}{c}47 \text { Portuguese and } 87 \\
\text { Greek family } \\
\text { businesses included } \\
\text { in the sample }\end{array}$ \\
\hline $\begin{array}{l}\text { Successors' } \\
\text { Perceived } \\
\text { Preparation for } \\
\text { Succession }\end{array}$ & $\begin{array}{l}\text { Perceived } \\
\text { Preparation for } \\
\text { Succession }\end{array}$ & $\begin{array}{l}\text { (1) I lack the skills } \\
\text { and knowledge to } \\
\text { manage the family } \\
\text { business; (2) I am not } \\
\text { yet ready and well } \\
\text { prepared to run the } \\
\text { business; (3) I do not } \\
\text { have the required } \\
\text { knowledge about the } \\
\text { family business; (4) I } \\
\text { am not able to take } \\
\text { over all the functions } \\
\text { that the previous } \\
\text { leader held; (5) The } \\
\text { process of succession } \\
\text { is very demanding in } \\
\text { terms of family } \\
\text { relations and the } \\
\text { sentimental burden is } \\
\text { high; (6) Family and } \\
\text { business matters are } \\
\text { complex and } \\
\text { intertwined; and (7) } \\
\text { We are facing family } \\
\text { related issues that I } \\
\text { cannot manage and } \\
\text { discuss with others }\end{array}$ & $\begin{array}{l}\text { Average of the } 7 \text { items } \\
\text { (Cronbach's alpha }=0.85 \text { ): low } / \mathrm{v} \text {. } \\
\text { low importance }=4 ; \text { moderate } \\
\text { importance }=3 \text {; high importance } \\
=2 ; \mathrm{v} \text {. high importance }=1 . \\
\text { Missing values were imputed as } \\
\text { the average of the available } \\
\text { variables }\end{array}$ & {$[15,56]$} & $\begin{array}{c}\text { Average }=2.20 \\
\text { Percentile } 10=1.24 \\
\text { Percentile } 90=3.20\end{array}$ & \\
\hline
\end{tabular}




\subsection{Sample}

The data for this research were gathered from an extensive European online survey conducted between April and July 2017 as part of FABUSS (Family Business Successful Succession), an ERASMUS+ project aimed at evaluating the conditions for successful succession in European family businesses. In our study, responses were provided by a convenience sample. The family businesses in this sample were identified with the support of the Portuguese Family Business Association and the Athens Chamber of Commerce and Industry. Despite the well-documented difficulties associated with defining a family business [84], the family businesses in our sample were those where families had the majority of the shares, control of the management, or responsibility for the top management [85]. By considering these conditions individually or jointly, we built a sample that was not affected by any legal, institutional, or practical issues that could hinder cross-country comparisons [86]. The results are based on responses by actual or intended family business successors from Portugal and Greece. In these countries, family businesses are broadly considered to be entities that are owned, controlled, or operated by different members of a family or small group of families. The responses reflect their perceptions regarding the problems and needs associated with family business succession. The initial sample consisted of 97 and 54 responses from Greek and Portuguese successors, respectively. Considering only usable responses yielded 87 and 41 workable responses for Greek and Portuguese successors, respectively. Family businesses are highly relevant in both countries, but there are several national characteristics that may influence succession. As per expectation states theory, these national characteristics include the effect on the definition of socially significant characteristics that influence social stratification and stereotypes [25]. Despite some cultural similarities such as the importance of men and the oldest son, there is a lack of research addressing cultural characteristics and their impact on family businesses in these countries.

\section{Results and Analysis}

Based on the procedures described earlier, we performed analysis of sufficient and necessary conditions and computed the intermediate solutions for high and low perceptions of preparation for succession for Portuguese and Greek businesses. The solutions for high perceptions appear in Table 2; Table 3 and are described in detail. The solutions for low perceptions appear in Tables 4 and 5 and are summarized for the purposes of brevity. Each of the tables identifies several alternative solutions. The columns represent configurations based on the presence or absence of the conditions listed in each of the rows. Alternative solutions lead to the same outcome, as follows: Tables 2 and 3 show configurations leading to high perceived preparation for succession in each country, whereas Tables 4 and 5 show configurations leading to low perceived preparation for succession in each country. Besides the equifinality resulting from the existence of alternative configurations of conditions, the solutions for high and low outcomes are not symmetrical, which is also valuable when attempting to understand how a certain outcome occurs. The overall solution consistencies and overall solution coverages are above the recommended thresholds and are thus considered informative. In the tables, the presence of a causal condition in any given solution is represented as $\bullet$, and the absence of a condition is represented as $\bigcirc$. Therefore, based on the data in Table 1, it is possible to interpret each solution (identified as S1, S2, S3, and S4). Solutions leading to high perceived preparation for succession in Portugal appear in Table 2. 
Table 2. Solutions for high perceived preparation in Portugal (successors' perceptions of preparation for succession).

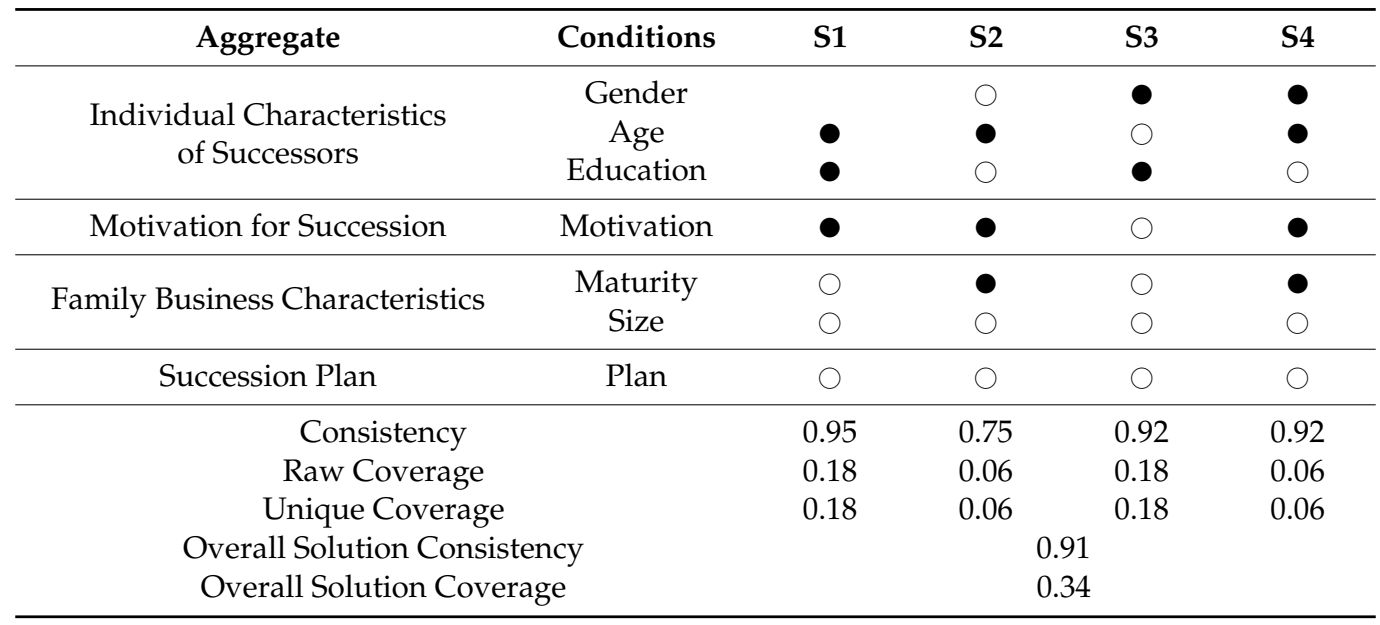

Note: $\bullet$ = causal condition present; $\bigcirc=$ causal condition absent.

Table 3. Solutions for high perceived preparation in Greece (successors' perceptions of preparation for succession).

\begin{tabular}{|c|c|c|c|c|c|c|c|c|c|c|c|c|c|c|}
\hline Aggregate & Conditions & S1 & $\mathrm{S} 2$ & S3 & S4 & S5 & S6 & S7 & S8 & S9 & S10 & S11 & $\mathrm{S} 12$ & S13 \\
\hline \multirow{2}{*}{$\begin{array}{c}\text { Individual } \\
\text { characteristics of } \\
\text { successors }\end{array}$} & Gender & 0 & 0 & & $\bigcirc$ & $\bullet$ & - & & $\mathrm{O}$ & $\bullet$ & - & $\mathrm{O}$ & $\bullet$ & 0 \\
\hline & Age & 0 & - & $\bigcirc$ & $\bullet$ & 0 & $\bigcirc$ & • & 0 & 0 & - & 0 & - & - \\
\hline $\begin{array}{l}\text { Motivation for } \\
\text { succession }\end{array}$ & Motivation & 0 & 0 & $\bullet$ & $\bullet$ & $\bullet$ & $\bullet$ & $\bullet$ & $\bullet$ & 0 & 0 & $\bullet$ & $\bullet$ & \\
\hline Succession plan & Plan & $\bigcirc$ & $\bigcirc$ & $\mathrm{O}$ & ○ & 0 & & 0 & 0 & 0 & $\bullet$ & $\bullet$ & $\bullet$ & 0 \\
\hline \multicolumn{2}{|c|}{ Consistency } & 0.91 & 0.76 & 0.81 & 0.85 & 0.97 & 0.93 & 0.89 & 0.92 & 0.92 & 0.82 & 0.82 & 0.95 & 0.82 \\
\hline \multicolumn{2}{|c|}{ Raw coverage } & 0.04 & 0.05 & 0.15 & 0.06 & 0.06 & 0.06 & 0.06 & 0.02 & 0.02 & 0.02 & 0.02 & 0.02 & 0.05 \\
\hline \multicolumn{2}{|c|}{ Unique coverage } & 0.04 & 0.02 & 0.11 & 0.02 & 0.02 & 0.02 & 0.06 & 0.02 & 0.02 & 0.02 & 0.02 & 0.02 & 0.02 \\
\hline \multicolumn{2}{|c|}{ Overall solution consistency } & & & & & & & 0.85 & & & & & & \\
\hline
\end{tabular}

Note: $\bullet$ = causal condition present; $\bigcirc=$ causal condition absent.

The analysis of necessary conditions revealed that the absence of a plan is a necessary condition for the high perception of preparation for succession in Portuguese family businesses. The intermediate solution consisted of four configurations of conditions.

In solution 1, the existence of older proactive successors linked to family microenterprises with no succession plan are central conditions. In this solution, successors have high levels of education, and the family businesses are in the second generation. Solution 2 also corresponds to older proactive successors in family microenterprises. The pattern points to male successors with low levels of education in highly mature businesses. Solution 3 corresponds to cases where young highly educated female successors work in family microenterprises, have low motivation for succession, and work in second-generation family businesses without a succession plan. Solution 4 corresponds to cases where older, female, and proactive successors with low levels of education work in highly mature family microenterprises that lack a well-defined succession plan. 
Table 4. Solutions for low perceived preparation in Portugal (successors' perceptions of preparation for succession).

\begin{tabular}{|c|c|c|c|c|c|c|c|c|}
\hline Aggregate & Conditions & S1 & S2 & S3 & S4 & S5 & S6 & S7 \\
\hline $\begin{array}{l}\text { Individual characteristics } \\
\text { of successors }\end{array}$ & $\begin{array}{c}\text { Gender } \\
\text { Age } \\
\text { Education }\end{array}$ & ○ & $\begin{array}{l}0 \\
0 \\
\bullet\end{array}$ & $\begin{array}{l}0 \\
0 \\
0\end{array}$ & $\begin{array}{l}0 \\
0 \\
\bullet\end{array}$ & $\begin{array}{l}0 \\
\bullet \\
\bullet\end{array}$ & $\begin{array}{l}0 \\
\bullet \\
\bullet\end{array}$ & $\begin{array}{l}0 \\
0 \\
0\end{array}$ \\
\hline Motivation for succession & Motivation & O & $\bullet$ & O & $\bullet$ & O & $\bullet$ & \\
\hline $\begin{array}{l}\text { Family business } \\
\text { characteristics }\end{array}$ & $\begin{array}{l}\text { Maturity } \\
\text { Size }\end{array}$ & ? & ? & ○ & 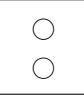 & $\bigcirc$ & $\begin{array}{l}0 \\
\bullet\end{array}$ & ? \\
\hline Succession plan & Plan & O & & O & O & O & 0 & O \\
\hline Consistency & & 0.85 & 0.89 & 0.78 & 0.94 & 0.82 & 0.77 & 0.89 \\
\hline Raw coverage & & 0.17 & 0.07 & 0.09 & 0.04 & 0.07 & 0.15 & 0.11 \\
\hline Unique coverage & & 0.13 & 0.07 & 0.09 & 0.04 & 0.07 & 0.15 & 0.11 \\
\hline Overall solution consistency & & & & & 0.83 & & & \\
\hline Overall solution coverage & & & & & 0.66 & & & \\
\hline
\end{tabular}

Note: $\bullet$ causal condition present; $\bigcirc=$ causal condition absent.

Table 5. Solutions for low perceived preparation in Greece (successors' perceptions of preparation for succession).

\begin{tabular}{|c|c|c|c|c|c|c|c|c|c|c|c|}
\hline Aggregate & Conditions & S1 & S2 & S3 & S4 & S5 & S6 & S7 & S8 & S9 & S10 \\
\hline \multirow{2}{*}{$\begin{array}{c}\text { Individual } \\
\text { characteristics of } \\
\text { successors }\end{array}$} & Gender & 0 & $\bigcirc$ & & $\bigcirc$ & 0 & $\bullet$ & - & 0 & $\bigcirc$ & $\bullet$ \\
\hline & $\begin{array}{c}\text { Age } \\
\text { Education }\end{array}$ & $\begin{array}{l}0 \\
\bullet\end{array}$ & $\bullet$ & $\bullet$ & ○ & • & $\bullet$ & ? & $\begin{array}{l}0 \\
0\end{array}$ & $\bullet$ & $\bigcirc$ \\
\hline Motivation & Motivation & & $\bullet$ & $\bullet$ & & $\bullet$ & • & 0 & $\bullet$ & 0 & $\bigcirc$ \\
\hline $\begin{array}{l}\text { Family business } \\
\text { characteristics }\end{array}$ & $\begin{array}{l}\text { Maturity } \\
\text { Size }\end{array}$ & $\begin{array}{l}0 \\
0\end{array}$ & $\stackrel{\bullet}{\circ}$ & $\stackrel{\bullet}{0}$ & $\begin{array}{l}\bigcirc \\
\bullet\end{array}$ & $\bullet$ & 0 & • & $\begin{array}{l}0 \\
0\end{array}$ & $\begin{array}{l}0 \\
0\end{array}$ & $\begin{array}{l}0 \\
0\end{array}$ \\
\hline Succession plan & Plan & $\bigcirc$ & $\bigcirc$ & $\bigcirc$ & - & - & - & & - & - & • \\
\hline \multicolumn{2}{|c|}{ Consistency } & 0.93 & 0.95 & 0.96 & 0.84 & 0.84 & 0.93 & 0.80 & 0.74 & 0.98 & 0.88 \\
\hline \multicolumn{2}{|c|}{ Raw coverage } & 0.05 & 0.07 & 0.05 & 0.06 & 0.06 & 0.05 & 0.06 & 0.02 & 0.02 & 0.02 \\
\hline \multicolumn{2}{|c|}{ Unique coverage } & 0.05 & 0.05 & 0.02 & 0.02 & 0.02 & 0.05 & 0.06 & 0.02 & 0.02 & 0.02 \\
\hline \multicolumn{2}{|c|}{ Overall solution consistency } & \multicolumn{10}{|c|}{0.89} \\
\hline \multicolumn{2}{|c|}{ Overall solution coverage } & \multicolumn{10}{|c|}{0.40} \\
\hline
\end{tabular}

Note: $\bullet$ = causal condition present; $\bigcirc=$ causal condition absent.

In summary, solutions for Portugal indicate that successors have high perceptions of their readiness for succession when there is no succession plan, usually when the business is a family microenterprise. Gender, age, and motivation are usually important factors affecting the perceptions of successors. These conditions combine to form different patterns explaining successors' perceptions. For Greek family businesses, no conditions were found to be necessary. The intermediate solution appears in Table 3.

The results reveal 13 solutions for Greek family businesses. There is therefore greater diversity in the configurations of conditions that lead to high perceived preparation for succession.

Solution 1 implies that successors have high perceived preparation for succession when they are young non-proactive males in small and medium-sized, and highly mature, family businesses that do not have succession plans. In comparison, solution 2 corresponds to successors that are older, highly educated, and non-proactive males in family microenterprises that lack succession plans. In solution 3 , gender is unimportant, and the absence of a succession plan is combined with young, educated, and proactive successors in small and medium-sized second-generation family businesses.

Solution 4 corresponds to micro-sized second-generation businesses with succession plans and older male successors who are proactive. Solution 5 coincides with solution 4 in terms of the successor's 
motivation and the maturity of the family business, but it differs in that it refers to young women in small and medium-sized family businesses without succession plans. In solution 6, the motivation and maturity are the same as in solutions 4 and 5 , but the existence of a succession plan is not relevant. In solution 6, successors are young well-educated women in large family businesses.

Solution 7 corresponds to small and medium-sized, highly mature family businesses that lack succession plans with older, well-educated, and proactive successors. Solution 8 refers to young, less educated, and proactive males in micro-sized second-generation family businesses that lack succession plans. Solution 9 also corresponds to businesses that lack succession plans, although these businesses are micro-sized and highly mature and the successors are non-proactive, young, and well-educated women.

The presence of a succession plan is a condition of solutions 10,11, and 12. Solution 10 refers to older, well-educated, and non-proactive female successors in micro-sized second-generation family businesses. Solution 11 refers to young, well-educated, and proactive male successors in small and medium-sized highly mature family businesses. Solution 12 refers to older proactive women with little formal education in small and medium-sized second-generation family businesses.

Finally, solution 13 refers to old well-educated male successors in micro-sized second-generation family businesses without succession plans.

To complement this analysis, we identified and analyzed the configurations of conditions that lead to successors' low perceived preparation for succession. In Portuguese family businesses, the absence of a succession plan is a necessary condition, and a high level of education is an almost necessary condition for low perceived preparation. The solutions for low perceived preparation for succession in Portugal appear in Table 4.

In most solutions for low perceived preparation, successors are male. Younger successors perceive themselves as less prepared for succession than older successors do. However, in two solutions, older successors also feel they are not prepared. In most solutions, successors have high levels of education, and family businesses are small or medium-sized, but low perceived preparation also occurred when successors have low levels of education and work in family microenterprises. High or low levels of motivation to succeed and of the maturity of the family business can be found in configurations leading to low perceived preparation.

Finally, there are no necessary conditions for low perceived preparation in Greek family businesses. The results of the fsQCA appear in Table 5.

As in the analysis of high perceived preparation for succession in Greek family businesses, a workable set of configurations remained elusive. The analysis yielded 10 possible solutions. In Greek family businesses, there is widespread pessimism in terms of preparation for succession by male successors; in only 3 of the 10 possible solutions does this happen for women. Older successors tend to be more pessimistic and have low perceived preparation for succession ( 7 out of 10 solutions). High motivation for succession is apparently ambiguous because 5 out of 10 possible solutions include high motivation, but lead to a low perceived preparation for succession. The existence of a succession plan does not seem to combat this feeling, as follows: In 6 out of 10 possible solutions for low perceived preparation for succession, family businesses have a succession plan. Moreover, successors in micro-sized second-generation family businesses are more likely to feel unprepared for succession. This situation is reflected by 6 out of 10 possible solutions.

In summary, each solution by itself presents an almost unique pattern that prevents the characterization of broad patterns that lead successors to develop low perceived preparation for succession in Greece.

\section{Discussion}

Our results show that individual characteristics of successors (i.e., gender, age, and level of education) influence their perceptions of preparation for family business succession. P1 is confirmed. Gender [9,40-42] and age, either jointly or in isolation, are highly important in determining successors' 
perceptions of preparation for the succession process. This finding applies to both low and high perceived preparation, although men seem more likely to have low perceived preparation for succession than women do in Portugal, which is an interesting outcome given the criticism [4] leveled at the lack of attention paid to "gender dynamics" in the literature. A high level of education creates the conditions to furnish successors with the awareness of the difficulty of the task ahead $[10,53]$ and does not necessarily give them a high perceived preparation for succession. This finding indicates a need for future research to analyze the correspondence between the successor's education and training and the needs of the family business. Such studies should consider, for instance, the relationship with the predecessor, the implications for knowledge transfer and self-confidence, and the implications for perceived success $[4,5]$, as well as the importance of a long-term approach to the successor's education and training and the influence such an approach might have on the relationship with the business's employees [14]. However, it is also important to consider that this feeling of readiness depends on other issues, such as family business characteristics (e.g., maturity and size) and difficulties surrounding the management of conflict between family members [11].

Although we may expect the type of motivation for succession to correspond to successors' perceptions of preparation for succession, the results show that successors' motivation may have different implications. These different implications present an alternative perspective on the importance of the affective and the normative dimensions or other causes of commitment [5,17]. The range of solutions in which motivation is either high or low implies that we cannot establish a specific direction for the relationship between motivation and successors' perceptions of preparation for succession. Despite being important, characteristics of family businesses-maturity (or the generation of the family managing the business) and size (or the number of employees) - on their own are less important in explaining successors' high perceptions of preparation for succession. Size seems to be more relevant than maturity to determine perceptions, whereas successors in small or medium-sized family businesses have lower perceived preparation for succession [11,60]. P2 and P3 are confirmed.

The existence of a succession plan is crucial in determining successors' perceptions of preparation for succession $[20,35,66,67]$. P4 is partially confirmed because, in Greece, different solutions link both the presence and absence of a succession plan to high or low perceived preparation. In Portugal, the long-term orientation is lower, so in businesses without succession plans, successors may have high or low perceived preparation. Well-established succession plans show the potential to increase ex-ante cooperation between business stakeholders, namely through the prior participation of successors in the strategic processes of family businesses, thereby facilitating smooth and successful succession and increasing the successors' perceptions of capacity for succession. Under such conducive conditions, strong family business performance can almost be guaranteed [87]. However, as Gilding et al. [4] reported, the existence of a succession plan is preceded by different levels of family business continuity and family harmony motivations, which are not addressed in this analysis and may help explain the existence of distinct configurations.

Finally, considering the arguments supporting the importance of cross-national research and specific traits, such as collectivism (e.g., [5]), the analysis shows that the configurations associated with successors' perceptions vary according to the context. In the case of Portugal, the patterns that lead to high or low perceived preparation for succession are clear, whereas in the case of Greece, a larger number of possible solutions implies that intrinsic differences are causing such contrasting results for these two countries. These differences may arise from major cultural differences that influence social stratification, as per expectation states theory [25]. These differences may relate to social traditions, the role of women in business, or even support for family businesses and entrepreneurship in these countries. P5 is confirmed. Context matters, and there are considerable differences in terms of the patterns that lead to high or low perceived preparation for succession. The solutions for Portugal were observed to be different from those for Greece. Differences between Portugal and Greece in terms of successors' high and low perceived preparation for succession, which affects successors' self-efficacy potential [81], can be explained by different cultural and economic conditions. 
We also found it easier to identify patterns that lead to high or low levels of perceived preparation for succession in Portugal. In Greece, however, the large number of possible solutions implies that it is less easy to characterize the patterns that lead to high or low perceived preparation for succession.

\section{Conclusions and Contributions}

One fundamental premise of this paper is that successors' perceptions of preparation to run the family business influence the self-efficacy and therefore the success of the transition from one generation to the next in the family business. By knowing the conditions required for successful succession, we can improve conditions for the sustainability of family businesses. Doing so not only has socioeconomic implications, but also environmental implications, when considered as a broad expression of social development. The environmental consequences of family businesses are as important as the consequences of family businesses in terms of the economic development of many European regions.

Studies of the perceptions that family business successors have of their preparation for succession are lacking. Given this research gap and the importance of these businesses in economies around the world, we drew on expectation states theory and fsQCA methodology to analyze data on family businesses in Greece and Portugal. Our aim was to investigate the effect of individual and family business characteristics, motivation for succession, the existence of a succession plan, and context on successors' perceptions of preparation for succession.

As described in the previous sections, the results are consistent with the research propositions. Different configurations of conditions are associated with high and low levels of perceived preparation, and these configurations differ according to context, although not always according to the predictions found in the literature. This finding reveals the difficulty in conceptualizing successors' perceptions, which seem to be highly sensitive to the conditions analyzed in this paper and, probably, other unexplored conditions, especially in the case of Greek family businesses.

The results of this research are relevant for several reasons. First, for family businesses, the results highlight the importance of working with successors to understand their perceptions of preparation for succession. The results show that similar conditions with minor differences may lead to very different perceptions and these perceptions will, in turn, influence the success of the succession process via self-efficacy. Second, for national or regional authorities and universities focused on creating a context that is conducive to successful family businesses, these results reveal that no single path leads to the desired outcomes in terms of success of the succession process. This finding implies that, despite the consensus on the importance of this issue, actions should cover several areas of intervention. Finally, for scholars, this study shows how fsQCA can be useful in family business research and opens new directions for the study of family businesses. More specifically, this study highlights the need for further research on family business succession because this field still has notable research gaps.

\section{Limitations and Future Research}

The main limitations of this study relate to the evolution of family business dynamics over the years and across generations. Thus, our analysis is restricted in time and our conclusions are valid only for the present situation.

Another limitation of this study relates to the fact that in expectation states theory, hierarchy is important to explain different patterns for social positioning and the consideration of social actors. Although hierarchy can also be important to explain different patterns of success in family business succession, this was not considered in the survey used to collect data for this study. Further research should consider this variable to complement the results of this study.

The economic climate affects family business performance. Consequently, it also affects the willingness of successors to pursue their own career in the family business or seek better prospects outside the family business. We did not study these variables in our research, so this issue should be addressed by other studies in the future. 
Future research can consider these limitations to develop further analysis based on different samples and the conclusions presented in this study.

Author Contributions: J.A.P. and T.C. were responsible for conceiving the study, whose results are reported and discussed in this paper. J.A.P., T.C., and J.H. designed the method. The formal analysis was conducted by J.A.P. and R.R. The original draft was prepared by J.A.P., and T.C. J.A.P., T.C., and R.R. then reviewed and edited the manuscript. Funding was acquired by J.H. and J.A.P.

Funding: The data for this study were collected as part of FABUSS (www.fabuss-project.eu), an ERASMUS+ project (2016-3-EL02-KA205-002673) aimed at evaluating the conditions for successful succession in European family businesses.

Acknowledgments: The authors thank Professor J. Augusto Felício from ISEG-Lisbon School of Economics and Management at the ULisboa for his careful reading and valuable suggestions.

Conflicts of Interest: The authors declare no conflict of interest.

\section{References}

1. Magazine, T. The Economic Impact of Family Business. Tharawat Mag. 2014, 22. Available online: https: //www.tharawat-magazine.com/magazine/issue-22-economic-impact-family-business/\#gs.fh55hl (accessed on 2 July 2019).

2. Adjei, E.K.; Eriksson, R.H.; Lindgren, U. Social proximity and firm performance: The importance of family member ties in workplaces. Reg. Stud. Reg. Sci. 2016, 3, 304-320. [CrossRef]

3. Byrne, J.; Fattoum, S.; Thébauld, S. A suitable boy? Gendered roles and hierarchies in family business succession. Eur. Manag. Rev. 2018, 1-18. [CrossRef]

4. Gilding, M.; Gregory, S.; Cosson, B. Motives and outcomes in family business succession planning. Entrep. Theory Pract. 2015, 39, 299-312. [CrossRef]

5. Cabrera-Suárez, M.K.; Martín-Santana, J.D. Successor's commitment and succession success: Dimensions and antecedents in the small Spanish family firm. Int. J. Hum. Resour. Manag. 2012, 23, 2736-2762. [CrossRef]

6. Barbera, F.; Bernhard, F.; Nacht, J.; McCann, G. The relevance of a whole-person learning approach to family business education: Concepts, evidence, and implications. Acad. Manag. Learn. Educ. 2015, 14, 322-346. [CrossRef]

7. Bork, D. Family Business, Risky Business; AMACON: New York, NY, USA, 1986.

8. Nelton, S. Love and in Business: How Entrepreneurial Couples Are Changing the Rules of Business and Marriage; Wiley: New York, NY, USA, 1986.

9. Salganicoff, M. Women in family business: Challenges and opportunities. Fam. Bus. Rev. 1990, 3, 125-138. [CrossRef]

10. Morris, M.H.; Williams, R.W.; Nel, D. Factors influencing family business succession. Int. J. Entrep. Behav. Res. 1996, 2, 68-81. [CrossRef]

11. Venter, E.; Boshoff, C.; Maas, G. The influence of successor-related factors on the succession process in small and medium-sized family businesses. Fam. Bus. Rev. 2005, 18, 283-303. [CrossRef]

12. Barach, J.A.; Gantisky, J.B. Successful succession in family business. Fam. Bus. Rev. 1995, 8, 131-155. [CrossRef]

13. Yoo, S.S.; Schenkel, M.T.; Kim, J. Examining the impact of inherited succession identity on family firm performance. J. Small Bus. Manag. 2014, 52, 246-265. [CrossRef]

14. Cater, J.J., III; Justis, R.T. The development of successors from followers to leaders in small family firms: An exploratory study. Fam. Bus. Rev. 2009, 22, 109-124. [CrossRef]

15. Gagne, M.; Sharma, P.; De Massis, A. The study of organizational behavior in family business. Eur. J. Work. Organ. Psychol. 2014, 23, 643-656. [CrossRef]

16. Hatak, I.R.; Roessl, D. Relational competence based knowledge transfer within intrafamily succession: An experimental study. Fam. Bus. Rev. 2015, 28, 10-25. [CrossRef]

17. Sharma, P.; Irving, P.G. Four bases of family business successor commitment: Antecedents and consequences. Entrep. Theory Pract. 2005, 29, 13-33. [CrossRef]

18. Chung, C.-N.; Luo, X.R. Leadership succession and firm performance in an emerging economy: Successor origin, relational embeddedness, and legitimacy. Strateg. Manag. J. 2013, 34, 338-357. [CrossRef] 
19. Eklund, J.; Palmberg, J.; Wiberg, D. Inherited corporate control and returns on investment. Small. Bus. Econ. 2013, 41, 419-431. [CrossRef]

20. Mazzola, P.; Marchisio, G.; Astrachan, J. Strategic planning in family business: A powerful developmental tool for the next generation. Fam. Bus. Rev. 2008, 21, 239-258. [CrossRef]

21. DeNoble, A.; Ehrlich, S.; Singh, G. Toward the development of a family business self-efficacy scale: A resource-based perspective. Fam. Bus. Rev. 2007, 20, 127-140. [CrossRef]

22. Pyromalis, V.D.; Vozikis, G.S. Mapping the successful succession process in family firms: Evidence from Greece. Int. Entrep. Manag. J. 2009, 5, 439-460. [CrossRef]

23. Stamm, I.; Lubinski, C. Crossroads of family business research and firm demography-A critical assessment of family business survival rates. J. Fam. Bus. Strateg. 2011, 2, 117-127. [CrossRef]

24. Ridgeway, C. Framed by Gender: How Gender Inequality Persists in the Modern World; Oxford University Press: Oxford, UK, 2011; ISBN-13 9780199755776. [CrossRef]

25. Correll, S.J.; Ridgeway, C.L. Expectation States Theory. In Handbook of Social Psychology; Delamater, J., Ed.; Springer: New York, NY, USA, 2003; pp. 29-51.

26. Berger, J.; Conner, T.L.; Fisek, M.H. Expectation States Theory: A Theoretical Research Program; Winthrop: Cambridge, MA, USA, 1974.

27. Berger, J.; Fisek, M.H.; Norman, R.; Zelditch, M. Status Characteristics and Social Interaction; Elsevier: New York, NY, USA, 1977.

28. Berger, J.; Zelditch, M. Status, Power, and Legitimacy: Strategies and Theories; Transaction: New Brunswick, NJ, USA, 1998.

29. Barach, J.A.; Gantisky, J.; Carson, J.A.; Doochin, B.A. Entry of the next generation: Strategic challenge for family business. J. Small Bus. Manag. 1988, 26, 49-56.

30. Brockhaus, R.H. Family business succession: Suggestions for future research. Fam. Bus. Rev. 2004, 17, 165-177. [CrossRef]

31. Cabrera-Suárez, K.; De Saá-Pérez, P.; García-Almeida, D. The succession process from a resource and knowledge-based view of the family firm. Fam. Bus. Rev. 2001, 14,37-46. [CrossRef]

32. Ciampa, D.; Watkins, M. The successor's dilemma. Harv. Bus. Rev. 1999, 77, 161-168.

33. Kaye, K. Is succession such a sweet dream? Fam. Bus. Rev. 1999, 10, 15-17.

34. Ward, J.L. Keeping the Family Business Healthy: How to Plan for Continuing Growth, Profitability and Family Leadership; Jossey-Bass: San Francisco, CA, USA, 1987.

35. Sharma, P.; Chrisman, J.J.; Chua, J.H. Predictors of satisfaction with the succession process in family firms. J. Bus. Ventur. 2003, 18, 667-687. [CrossRef]

36. Shepherd, D.A.; Zacharakis, A. Structuring family business succession: An analysis of the future leader's decision making. Entrep. Theory Pract. 2000, 24, 25-39. [CrossRef]

37. Audet, J.; Berger-Douce, S.; St-Jean, E. Perceptual barriers preventing small business owners from using public support services: Evidence from Canada. Int. J. Entrep. 2007, 11, 27-48.

38. Aldrich, H.E. Networking among women entrepreneurs. In Women-Owned Businesses; Hagan, O., Rivchum, C., Sexton, D.L., Eds.; Praeger: New York, NY, USA, 1989; pp. 13-132.

39. Cuba, R.; Decenzo, D.; Anish, A. Management practices of successful female business owners. Am. J. Small Bus. 1983, 2, 40-46. [CrossRef]

40. Harveston, P.D.; Davis, P.S.; Lyden, J.A. Succession planning in family business: The impact of owner gender. Fam. Bus. Rev. 1997, 10, 373-396. [CrossRef]

41. Dumas, C. Daughters in Family-Owned Businesses: An Applied Systems Perspective; Fielding Institute: Santa Barbara, CA, USA, 1989; Unpublished doctoral dissertation.

42. Dumas, C. Preparing the new CEO: Managing the father-daughter succession process in family business. Fam. Bus. Rev. 1990, 3, 169-181. [CrossRef]

43. Vera, C.F.; Dean, M.A. An examination of the challenges daughters face in family business succession. Fam. Bus. Rev. 2005, 18, 321-345. [CrossRef]

44. Nelson, T.; Constantinidis, C. Sex and gender in family business succession research: A review and forward agenda from a social construction perspective. Fam. Bus. Rev. 2017, 30, 219-241. [CrossRef]

45. Gottardo, P.; Moisello, A.M. Family firms, risk-taking and financial distress. Probl. Perspect. Manag. 2017, 15, 168-177. [CrossRef]

46. Lansberg, I.S. The succession conspiracy. Fam. Bus. Rev. 1988, 1, 119-143. [CrossRef] 
47. Murphy, L.; Lambrechts, F. Investigating the actual career decisions of the next generation: The impact of family business involvement. J. Fam. Bus. Strateg. 2015, 6, 33-44. [CrossRef]

48. Doescher, W.F. How to shake the family tree. D B Rep. 1993, July/August, 10-11.

49. Fenn, D. Are your kids good enough to run your business? INC 1994, August, 36-48.

50. Hyatt, J. Fathers and sons. INC 1992, May, 51-62.

51. Osborne, R.L. Second-generation entrepreneurs: Passing the baton in the privately-held company. Manag. Decis. 1991, 29, 42-46. [CrossRef]

52. Kimberly, J.R.; Evanisko, M.J. Organizational innovation: The influence of individual, organizational and contextual factors on hospital adoption of technological and administrative innovations. Acad. Manag. J. 1981, 24, 689-713.

53. Datta, D.K.; Guthrie, J.P. Executive succession: Organizational antecedents of CEO characteristics. Strateg. Manag. J. 1994, 15, 569-577. [CrossRef]

54. Royer, S.; Simons, R.; Boyd, B.; Rafferty, A. Promoting family: A contingency model of family business succession. Fam. Bus. Rev. 2008, 21, 15-30. [CrossRef]

55. Chrisman, J.J.; Chua, J.H.; Sharma, P. Important attributes of successors in family businesses: An exploratory study. Fam. Bus. Rev. 1998, 11, 19-34. [CrossRef]

56. Sharma, P.; Rao, S. Successor attributes in Indian and Canadian family firms: A comparative study. Fam. Bus. Rev. 2000, 13, 313-330. [CrossRef]

57. Cespedes, F.V.; Galford, R.M. Succession and Failure. Harv. Bus. Rev. 2004, 82, 31-42.

58. Sharma, P.; Chrisman, J.J.; Pablo, A.L.; Chua, J.H. Determinants of initial satisfaction with the succession process in family firms: A conceptual model. Entrep. Theory Pract. 2001, 25, 17-35. [CrossRef]

59. Handler, W.C. Succession in family business: A review of the research. Fam. Bus. Rev. 1994, 7, $133-157$. [CrossRef]

60. Stavrou, E. Succession in family businesses: Exploring the effects of demographic factors on offspring intentions to join and take over the business. J. Small. Bus. Manag. 1999, 37, 43-62.

61. Chua, J.H.; Chrisman, J.J.; Sharma, P. Succession and nonsuccession concerns of family firms and agency relationship with nonfamily managers. Fam. Bus. Rev. 2003, 16, 89-107. [CrossRef]

62. Molly, V.; Laveren, E.; Deloof, M. Family business succession and its impact on financial structure and performance. Fam. Bus. Rev. 2010, 23, 131-147. [CrossRef]

63. Cucculelli, M.; Micucci, G. Family succession and firm performance: Evidence from Italian family firms. J. Corp. Financ. 2008, 14, 17-31. [CrossRef]

64. Astrachan, J.H.; Kolenko, T.A. A neglected factor explaining family business success: Human resource practices. Fam. Bus. Rev. 1994, 7, 251-262. [CrossRef]

65. Blumentritt, T. The relationship between boards and planning in family businesses. Fam. Bus. Rev. 2006, 19, 65-72. [CrossRef]

66. McCann, J.E., III; Leon-Guerrero, A.Y.; Haley, J.D., Jr. Strategic goals and practices of innovative family businesses. J. Small Bus. Manag. 2001, 39, 50-59. [CrossRef]

67. Chrisman, J.J.; Chua, J.H.; Steier, L. Sources and consequences of distinctive familiness: An introduction. Entrep. Theory Pract. 2005, 29, 237-247. [CrossRef]

68. Botella-Carrubi, M.D.; González-Cruz, T.F. Context as a provider of key resources for succession: A case study of sustainable family firms. Sustainability 2019, 11, 1873. [CrossRef]

69. Miller, D.; Steier, L.; Le Breton-Miller, I. Lost in time: Intergenerational succession, change, and failure in family business. J. Bus. Ventur. 2003, 18, 513-531. [CrossRef]

70. Helin, J.; Jabri, M. Family business succession in dialogue: The case of differing backgrounds and views. Int. Small Bus. J. 2016, 34, 487-505. [CrossRef]

71. Arregle, J.-L.; Duran, P.; Hitt, M.A.; van Essen, M. Why is family firms' internationalization unique? A meta-analysis. Entrep. Theory Pract. 2017, 41, 801-831. [CrossRef]

72. Solon, G. Cross-country differences in intergenerational earnings mobility. J. Econ. Perspect. 2002, 16, 59-66. [CrossRef]

73. Venturelli, A.; Caputo, F.; Leopizzi, R.; Pizzi, S. The state of art of corporate social disclosure before the introduction of non-financial reporting directive: A cross country analysis. Soc. Responsib. J. 2018, 15, 409-423. [CrossRef] 
74. Peng, M.W.; Jiang, Y. Institutions behind family ownership and control in large firms. J. Manag. Stud. 2010, 47, 253-273. [CrossRef]

75. Ragin, C.C. Redesigning Social Inquiry: Fuzzy Sets and Beyond; The University of Chicago Press: Chicago, IL, USA, 2008.

76. Schneider, C.Q.; Wageman, C. Set-Theoretic Methods for the Social Sciences: A Guide to Qualitative Comparative Analysis; Cambridge University Press: Cambridge, UK, 2012.

77. Roig-Tierno, N.; Huarng, K.-H.; Ribeiro-Soriano, D. Qualitative comparative analysis: Crisp and fuzzy sets in business and management. J. Bus. Res. 2016, 69, 1261-1264. [CrossRef]

78. Kraus, S.; Richter, C.; Brem, A.; Cheng, C.-F.; Chang, M.-L. Strategies for reward-based crowdfunding campaigns. J. Innov. Knowl. 2016, 1, 13-23. [CrossRef]

79. Brenes, E.R.; Ciravegna, L.; Woodside, A.G. Constructing useful models of firms' heterogeneities in implemented strategies and performance outcomes. Ind. Mark. Manag. 2017, 62, 17-35. [CrossRef]

80. Crilly, D.; Zollo, M.; Hansen, M.T. Faking it or muddling through? Understanding decoupling in response to stakeholder pressures. Acad. Manag. J. 2012, 55, 1429-1448. [CrossRef]

81. Vassiliadis, S.; Vassiliadis, A. The Greek family businesses and the succession problem. Procedia Econ. Financ. 2014, 9, 242-247. [CrossRef]

82. Howorth, C.; Zahra Assaraf, A. Family business succession in Portugal: An examination of case studies in the furniture industry. Fam. Bus. Rev. 2001, 14, 231-244. [CrossRef]

83. Miralles-Marcelo, J.L.; Miralles-Quirós, M.D.M.; Lisboa, I. The impact of family control on firm performance: Evidence from Portugal and Spain. J. Fam. Bus. Strateg. 2014, 5, 56-168. [CrossRef]

84. Astrachan, J.H.; Klein, S.B.; Smyrnios, K.X. The F-PEC Scale of Family Influence: A proposal for solving the Family Business Definition Problem. Fam. Bus. Rev. 2002, 55, 45-57. [CrossRef]

85. Miller, D.; Minichilli, A.; Corbetta, G. Is Family Leadership always beneficial? Strateg. Manag. J. 2013, 34, 553-571. [CrossRef]

86. Allouche, J.; Amann, B.; Jaussaud, J.; Kurashina, T. Impact of Family Control on the performance and Financial Characteristics of Family versus Nonfamily Businesses in Japan: A Matched-Pair Investigation. Fam. Bus. Rev. 2008, 21, 315-329. [CrossRef]

87. Ghee, W.Y.; Ibrahim, M.D.; Abdul-Halim, H. Family business succession planning: Unleashing the key factors of business performance. Asian Acad. Manag. J. 2015, 20, 103-126. 